\title{
Accountant Profession Responding To Impact Worse In Economic Conditions.
}

\author{
Usep Mahmud ${ }^{1)}$; Sugito ${ }^{2)}$ \\ ${ }^{1,2)}$ The College of Administrative Sciences STIA MENARA SISWA \\ Email : usepmahmud@menarasiswa.ac.id
}

\section{ARTICLES \\ INFORMATION

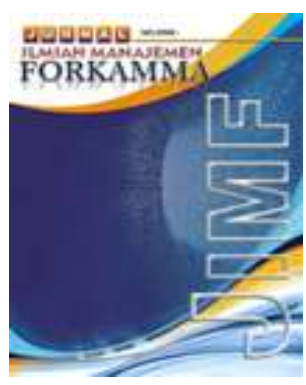 \\ JURNAL ILMIAH MANAJEMEN FORKAMMA}

ABSTRACT

Vol.3, No.2, Maret 2020

Halaman : $195-204$

(c) LPPM \& FORKAMMA

Prodi Magister Manajemen

UNVERSITAS PAMULANG
The economic crisis has already general some audit risks. Audit practices become more complex. Going concern issues, ligitation toward accounting profession, changes in laws and regulation affecting the profession have created the risk environment. Accounting profession responses such changes by managing them properly to aproaches that are used to mitigate such risks are the comprehensive approach, and the appropriate policies and procedures approach. Moreover Indonesian Accountant Association as a standart board Authority has issued some PSAK ( Indonesian GAAP ) and SPAP (Indonesia GAAS ) to provide the guidance for implementing audit engagement in the risk environment.

ISSN (online) : 2599-171X

ISSN (print) : :2598-9545

\section{Keyword :}

accounting profession, economic crisis, risk environment, risk management.

JEL. classification :

O15,

\section{Contact Author : \\ PRODI \\ MAGISTER MANAJEMEN \& FORKAMMA UNPAM \\ JL.Surya Kencana No.1 Pamulang \\ Tangerang Selatan - Banten \\ Telp. (021) 7412566, Fax (021) 7412491 \\ Email : \\ jurnalforkamma.unpam@gmail.com}




\section{A. INTRODUCTION}

The economic crisis that hit Southeast Asia had a significant impact on the survival of business entities. This change carries a risk for the accounting profession, if not careful in carrying out his profession, the accounting profession, in this case the auditor will be threatened by the continuity of his profession. The high level of uncertainty in the future as a result of the deteriorating economic conditions adds to the weight of the auditor's responsibility. The more diverse types of assignments that are not found in normal economic conditions, carry its own risks for the auditor.

In addition, the condition of countries in the Asian region which previously did not care much about the law had shifted to an increasingly lawful situation. Claims against auditors began to bloom. To respond to changes - changes that occur auditors need to protect themselves from the risk of demands that are not in place.

Various attempts were made by the auditor profession in responding to the effects of worsening economic conditions. The need to manage risk in order to avoid the threat of litigation is increasingly pressing. For this reason, the auditor profession has made various regulatory improvements that enable this profession to carry out its profession well.

Auditors can control or transfer risk through a comprehensive approach and the preparation of adequate policies and procedures. Audit risk begins from the process of accepting assignments from clients, the implementation of the assignment until the completion of the assignment. The auditor must have appropriate procedures and design policies that must be implemented by the parties involved.

Another response made was to put in order a number of new Statement of Financial Accounting Standards (PSAK) and the new Public Accountants Professional Standards (SPAP). The auditors also pay attention to regulations issued by Bank Indonesia and Bapepam that affect accounting treatment. High vigilance and caution in carrying out the profession is very necessary so that the auditor profession is not trapped in the threat of unwanted demands.

\section{B. RESEARCH METHODS}

Accounting research methods are defined as: The right method / steps to do something. The method is different from the methodology. Methodology comes from a method that means the right way or steps to do something while logi comes from the word logos which means science. So the methodology is the right way or steps to get knowledge. Research is an attempt to find, develop and test the truth of a science. Accounting (as an information system) is an information system that produces financial information to interested parties regarding the economic activities and conditions of a company. The results of the accounting process are called financial statements. Accounting (as a process) is the activity of collecting, analyzing, presenting in the form of numbers, classifying, recording, summarizing and reporting the activities / transactions of companies in the form of financial information. So the method of accounting research is a method / way or steps to find, develop and test the truth of a science in the field of accounting. Accounting as an information system will produce financial reports and accounting as a process will produce financial information.

So the object of accounting research is financial statements or financial information consisting of:

1) Statement of comprehensive income (Statement of Comprehensive Income).

2) Statement of changes in equity (Statement of Changes in Equity).

3) Statement of financial position (Statement of Financial Position).

4) Statement of cash flow (Statement of Cash Flows). 
5) Notes to the financial statements.

6) Statements of financial position at the beginning of the comparative period.

Classification of Research (Accounting) Accounting Classification of accounting research based on hypothesis testing can be divided into two, namely accounting research that tests research hypotheses and accounting research that tests statistical hypotheses. Accounting research that tests research hypotheses tries to prove the theory that has been proposed while accounting research that tests statistical hypotheses tries to prove the statistical hypotheses that have been submitted. Accounting research that examines research hypotheses uses data analysis techniques in the form of accounting analysis tools that consist of accounting formulas and financial ratios and uses descriptive statistics with monetary measurement units (money). Accounting research that tests statistical hypotheses uses data analysis techniques in the form of inferential statistical formulas both parametric and non-parametric. The unit of measurement for statistical data analysis can be in the form of a scale (for example a Likert scale) or in the form of monetary (money). Measurements in the form of scales measure respondents' perceptions or opinions of the object of accounting research while measurements in the form of monetary (money) measure the activities of accounting research objects with monetary (money).

\section{DISCUSSION}

1. Changes - Changes in Laws and Legislation - Invitations That Affect the Profession of Accountants and Clients.

There are a number of new regulations issued by regulatory authorities that have an impact on the accounting profession, including: Bapepam Regulation Through Kep 22, May 1998, Bapepam stated that public accountants and public companies have unlimited liability to investors who have suffered losses due to buying company shares, where the purchase is based on incorrect audit financial information. Bapepam has the right to examine audit work papers to obtain evidence of auditor disobedience in the preparation of financial statements. The auditor is also responsible for reporting to Bapepam for companies that do not comply with regulations and cause losses to investors or clients.

Sanctions for public accountants who do not comply with Bapepam No. 22 according to Government Regulation (PP) 45 of 1995 in the form of warnings of fines even to revoke licenses of practice.

Anti-Monopoly Law No. 5/1999 dated March 10, 1999 - Suspicion of violations of the Anti-Monopoly Law and IMF unfair competition. The IMF's proposal is to increase the auditor's legal responsibilities in preparing financial statements and disclosures and to increase the auditor's role in corperate governance through an audit committee, coordinating with government agencies and tax authorities.

Bank Indonesia regulations addressed to banks (April, 1999) Bank Indonesia issued a number of regulations aimed at banks which also had an impact on the accounting profession. These regulations include:

a. Banks - banks must comply with a management letter containing the results of an internal control review including compliance with PSAK.

b. Ban - the bank must know the audit report on IT systems and testing of existing programs, in relation to the 2000 plan.

c. Bank Indonesia can refuse the appointment of an auditor if the audit report does not reflect the actual financial condition of the bank. 
In addition to the above regulations, Bank Indonesia also issued other regulations that have an impact on accounting treatment, namely:

a. Capital Adequacy Ratio Requirements

b. Negative Spreads

Debt restructuring, debt - equity swaps.

Debt clarification.

c. Net open position requirements.

Legal Landing Limit Requirements.

d. Mergers and acquisitions.

e. Funds for recapitalization through the issuance of shares and government bonds annual financial statements and disclosures.

These regulations need to be considered by the auditor in carrying out audits because they have an impact on the treatment of accountants.

In addition to a number of laws and regulations above, the auditor also needs to pay attention to the issuance of the Bankruptcy Act (PP 87 of 1998) and the Corruption, Kousi and Nepotism Laws (KKN Law). The birth of a number of new laws and regulations will certainly increase the risk environment faced by the auditor.

\section{Going Concern Problems}

Almost all companies in Indonesia experience Going Concern as a result of the deteriorating economic conditions. Some of the things that trigger the Going Concern problem are the large losses suffered by the company. High debt to capital ratio, large short-term debt balance which is due soon. Large foreign currency loans, shortages and cash and access to cash, a shrinking market, problems with suppliers and customers, and the absence of a clear action plan from management.

In assessing whether an entrepreneur has a Going Concern or not, the main concern of the auditor is no longer aimed at how much wealth the company has in the future that is expected by the management of the auditor to no longer just accept management's view that everything is good. Even auditors should no longer put full trust in the guarantee given by the government that certain companies will not be closed.

Evaluation of the Going Concern must be more based on the results of the calculation of discounted cash flow. The auditor needs to know the exact source of the company's cash, and the company's ability and sufficient cash. If the problem is that the cash fund is fulfilled, the auditor still needs to know whether the company will be able to return the funds and what management will do to guarantee repayment of the funds. In other words cash becomes the main focus in a situation of deteriorating economic conditions, due to a very high degree of certainty in the future.

In a worsening economic situation going concern assessment is based more on the company's ability to continue its operations within the next 12 months. In other words, going concern assessment refers to the availability of cash funds to conduct business activities for the next 12 months. To arrive at a conclusion whether the company will have a going concern or not, the auditor must make a critical evaluation of management plans.

\section{Three Types of Main Risks in Audit Prams in Indonesia}

There are 3 main types of risks that are generally faced in audit practice in Indonesia. The 3 types of risk include: litigation, fraud and inadequate audit opinion caused by material misstatement of fraud information and inadequate disclosure.

a. Litigation: increasing legal responsibility in disciplining appropriate audit opinions. An audit can no longer arbitrarily provide an opinion, because society is 
increasingly sensitive to the mistakes made by the auditor. The auditor needs to think about losses and sanctions that must be faced, if there is a claim (litigation).

b. Froud: consequences that must be faced if there is fraud - fraud that is not able to be detected by the auditor during the assignment, and it turns out the fraud was discovered by another party. Fraud that can be discovered during assignments on the other hand also poses a risk to the auditor.

c. Improper audit options caused by material misstatement of financial information and inadequate disclosure. Opinions that are not appropriate will end up canceled for the auditor especially if the opinion is used as a basis for decision making by interested parties. In order for the auditor to avoid this kind of risk, the auditor needs to maintain the quality of the work carried out by the auditor needs to confirm in the engagement Letter limits on the auditor's responsibility, and that the auditor is not responsible material misstatement by the management.

\section{Risk Environment}

The risk environment faced by the auditor can be global, such as the increasing demands on the auditor and local nature resulting from the impact of worsening economic conditions. Several large public accounting firms have anticipated the threat of increasing demands. They feel it is necessary to emphasize the limited liability, indemnification and freedom from misstatements made by management (release from management). These things must be explicitly included in the assignment clause. The following are some examples of these clauses:

Limitation of Liability (adapted by The Big Five) PT.. aggress that ABC Firm's maximum liability for any reason, including $A B C$ Firm's negligence, ralating to the services rendered under this letter shall be limited to the fees paid to ABC Firm for the services or work product giving rise the liability. Reles from the management misrepresentation.

Because of the important og management's representation to an effective aid, PT .... agrees to release ABC Firm and its personnel from any liability, claims and costs relating to our services under this letter attributable to any misrepresentations by management, whether make orally or in writing.

Indemnification.

As further consideration for $A B C$ Firm providing the services set out in this letter, the company agrees to independently and hold HRMless ABC Firm and Ots personnel from any claims, demands, actions, proceedings, losses, damages, liabilities, costs and expenses whatever, whatever brought or incurred by the company or any third parties related to, or arising directly from or out of the service provided under this letter.

Environmental risk, which is the impact of deteriorating economic conditions, has led to an increase in qualified going concern opinions and disclaimers for assignments in 1998. In that year generally companies experienced significant capital deficits, financial losses caused by losses exchange rates and bear financial costs and operational losses.

The number of banks that have been taken over, have been closed down or have been capitalized (BBKU, BBO, BTO Recap) as well as companies experiencing problems with defaulting due obligations, companies that are in the process of renegotiating their debts with creditors, companies that are currently in the process on the verge of bankruptcy or bad debtor is one of the risk environments that must be faced by the auditor. In addition there are companies that go public in the delisting category according to the Jakarta Stock Exchange (JSX).

The issue of qualified opinion and disclaimer continued in 1999, although some companies began reporting earnings even though they were still small and profit from 
the exchange rate. On the other hand capital inadequacy, difficulties to collect receivables, debt restructuring and bad debtors continue and there are still several public companies that are delisting.

The risk environment faced by auditors is also increasingly complex with the role of auditors in helping governments overcome problems - issues related to corruption, collusion and nepotism. The auditor is asked to audit state-owned companies, government financial transactions and auditing of companies that receive funds from external or external sources.

Besides this, the diversity of assignments such as auditing of companies that are in the process of liquidation, auditing and due diligence of recapitalization banks, banks that have their operations frozen or banks taken over, create a new risk environment for auditors to face. Issues such as corporate governance, transparency and increasingly intense accountability also contribute to the emergence of new risks for the accounting profession.

\section{Importance of managing risk (risk management)}

The impact of globalization in all fields supported by advances in information technology has driven the acceleration of information. Countries in Southeast Asia which initially did not really question the law, have seen the application of the law in other countries, especially developed countries such as the United States and Australia. This encourages them to become more aware of the legal responsibilities that can be demanded from auditors. The demand for public accountants feels even greater than in previous periods.

Professional auditors must be aware of this development, a slight misstep will have fatal consequences for the continuity of their profession.

Losses that can be experienced are related to risks include reputation issues, loss of clients, loss of rights to practice and financial losses. Auditors who have a bad reputation will be avoided by the client, thus the opportunity to practice is also hampered and will ultimately lead to financial losses.

In addition to the losses that will be experienced if you neglect risk management, the auditor must also bear the various costs (costs) associated with risk. The cost of the loss suffered can be tangible for example: legal defense, insurance, rework, fines, and intangible costs including: bad publicity, lost of client and lost of reputation. Intangible costs are usually more severe for auditors because they have an impact on the survival of their profession.

\section{Process for controlling or transferring risk.}

Risks - the above risks can not be avoided by the auditor, but at least the auditor can do the process to control or move the risks faced. This can be done through a comprehensive approach and through the establishment of appropriate policies and procedures.

A comprehensive approach is carried out for each type of work of each individual on the audit team. Supervision must be strictly carried out, to maintain the quality of work. The work of each team member must be accountable, because the quality of work of each individual contributes to the overall quality of work.

Another approach that can be taken to control or transfer risk is to formulate policies and procedures that can be done from the moment of accepting the job (job acceptance) and at the time of the execution of the job (job execution).

a. Job Acceptance

The risk faced by the auditor begins when the process of deciding to accept the assignment offered by the client. In deciding whether to accept or reject the offer of assignment from a client, the auditor needs to pay attention to the following: 
b. Scope of assignment (scope of Practice) The auditor must consider the expertise possessed in deciding to accept the assignment offer from the client. In addition, regulatory issues need to be considered by the auditor. The auditor must refrain from violating established rules, for example the rules regarding independence. The desire of auditors to establish business with clients. Auditors need to do due diligence to find out the background of the company that assigns them. Economic issues also need special attention including compliance with the company's strategy / Further the auditor needs to review the level of courage to conduct business relations with the company, after considering various risks that will be faced.

c. Job Execution.

Before starting to carry out work, an engagement letter containing the rights of the auditor is needed, the desired achievements and limits of the assignment made by the auditor. The auditor must also be aware of issues relating to the company where the auditor will assign assignments. The auditor needs to consult the problems faced in the implementation of the assignment to the management, so that management will participate in thinking of solutions that do not harm each party.

7. Issuance of a number of new Accounting Standard Requirements (PSAK) and Public Accountant Professional Standards (SPAP).

In addition to taking a comprehensive approach and formulating appropriate policies and procedures, the accounting profession through the Indonesian Institute of Accountants has issued a number of new PSAKs and SPAPs. This is done to meet the need for guidelines for implementing auditing in increasingly complex audit practices.

a. PSAK (Indonesian GAAP). Anticipating changes - changes that occur during the crisis, the regulators in this case the Indonesian Institute of Accountants (IAI) responded by issuing a number of new PSAK including:

1) PSAK 46 = International Accounting Standards (IAS) 12. Accountants for deferred income tax accounting in effect starting January 1999 for companies that go public and January 2001 for companies that have not yet gone public. This PSAK arises because of the need to account for the tax consequences in the current and future periods for the recovery of the carrying value of assets recognized on the company's balance sheet, the settlement of the carrying value of the obligations recognized on the company's balance sheet.

2) PSAK 48 = IAS 36. Impairment of Assets which took effect in January 2000. This PSAK regulates the accounting treatment of impaired assets and the consequences of impairment.

3) PSAK 55 = Statement of financial accounting standards (SFAS) 133. Accounting for derivatives and hedging. This statement regulates accounting treatment for uk certain derivative instruments that are attached to other agreements and hedging activities.

4) PSAK 52 which in certain cases is the same as SFAS 52. This PSAK regulates the currencies used by companies that use currencies other than rupiah as reporting currencies, where this is possible to be carried out considering the fluctuating value of the rupiah.

5) PSAK 54 = SPAS 15

Accounting for debt and debt restructuring problems. This statement sets the standard for financial accounting and reporting on the restructuring of bad debts, both for debtors and creditors. 
6) PSAK 51.

Accounting for quasi reorganization. This statement regulates the implementation of accounting procedures that regulate companies which recapitalize their equity by eliminating deficits and the return value of all assets and liabilities without going through legal reorganization.

b. Professional Standards for Public Accountants (SPAP) / Indonesia GAAS

In addition to PSAK, standards for auditing are also increasingly being developed in response to the changes that occur as described above. New regulations that arise include those related to:

1) Audit for political parties (required by Law No. 3 of 1999) which must be reported to the Election Commission

2) Sanctions to auditors who give inappropriate opinions.

3) The impact of Bapepam's decision No. 49 concerning deferral of exchange rate losses to audit opinions (IPSA 29.04) January, 1999.

4) The proposed standard for attestation is more or less the same as that of the Statement on American Auditing Standarts (SAS).

5) Auditor's consideration of worsening economic conditions (IPSA 30.01), March 1999.

\section{Management Plan}

For companies that are affected by the deteriorating economic conditions and these impacts affect their survival, the company needs to develop management plans. These plans describe what actions will be taken by management to overcome the going concern problem.

The plans made by management become the basis for the auditor to conduct further assessments. An in-depth evaluation of management plans must be carried out to provide an assessment of the feasibility of the plans made. To gain confidence in the feasibility of the management plan the auditor will do the following:

a. What are these management plans?

b. Are the plans made according to the situation at hand?

c. What are the key elements of these management plans?

d. Are these plans able to bring the company to a better condition?

e. Are there audit evidences?

After critically evaluating management plans, if the auditor concludes that there is still great doubt about what will happen in the future the auditor must disclose events and situations which the auditor considers to be very fundamental in the notes to the financial statements. In addition, the auditor must also add an additional paragraph that emphasizes the problem that becomes the auditor's concern (metter of paragraph empasis).

Companies that experience going concern problems but do not draw up a management plan can be given a going concern qualification opinion. If there are large doubts, the auditor can give a disclaimer opinion.

\section{Interest Accounting standard statement (IPSA) $\mathbf{3 0 . 0 1}$}

The independent auditor's consideration of the impact of the deteriorating economic conditions of Indonesia on the survival of the entity is stated in IPSA 30.01. The issuance of IPSA is also one of the efforts of the accountant profession to have a stronger foundation in providing opinions on the survival of the entity. 


\section{CONCLUSION.}

Based on the discussions that have been obtained previously, the following important conclusions can be drawn:

1. There are a number of new laws and regulations that have arisen in response to the impact of the economic deterioration which has influenced the accounting profession.

2. Auditors face an increasingly complex risk environment both global and local.

3. Users of audit reports are increasingly aware of the legal responsibilities of auditors who allow auditors to be sued if the audit report issued is detrimental to the user of the audit report.

4. Professional accountants respond to changes that occur as a result of deteriorating economic conditions by managing risks so that risks can be controlled and transferred through a comprehensive approach and adequate placement of policies and procedures.

5. Professional accountants through the Indonesian Institute of Accountants also published a number of new PSAKs and SPAPs to meet the need for regulations that support increasingly complex audit practices. 


\section{REFERENCES}

Abdul Kadim, K., \& Nardi Sunardi, S. (2018). Determinant Of Company's Likuidity And It's Implications On Financial's Performance Of Ritail Trade Company's In Indonesia At The Period Of 2008-2017. Global and Stockhastic Analysis, 5(7), 235-247.

Abdul Kadim, K., \& Nardi, S. (2018). Eviews Analysis: Determinant Of Leverage And Company's Performance. Global and Stochastic Analysis (GSA), 5(7), 249-260.

Abdul Kadim, K., Nardi Sunardi, S., Hendro Waryanto, W., Dessy Adelin, A., \& Endang Kusmana, K. (2018). The Effects Of Bank Soundness With The RGEC Approach (Risk Profile, Good Corporate Governance, Earnings, Capital) Of Leverage And Its Implications On Company's Value Of State Bank In Indonesia For The Period Of 2012-2016. IJER (International Journal of Economic Research), 15(11), 41-52.

Aren A. Alvin, Lobeeke James K (1971). Auditing An Integrated Approach. Upper Saddle River New Jersey: Prentice Hall Inc.

Boynton C. William, Kell Walter G. (1996) Modern Auditing Sixt Edition. John Wiley Sons Inc.

Indonesian Institute of Accountants (1994). Professional Standards for Public Accountants. Yogyakarta: Publication Section of the School of Economics (YKPN).

Indonesian Institute of Accountants (1999). Statement of Financial Accounting Standards, Jakarta: Salemba Empat Publisher.

Kadim, A., \& Sunardi, N. (2019, May). Eviews Analysis; Determinan Tourism, Restaurant and Hotel Company's Soundness and Performance. In Proceeding Interuniversity Forum for Strengthening Academic Competency (Vol. 1, No. 1, pp. 332-340).

Nardi Sunardi, E. A., Kadim, A., Tumanggor, M., \& Oktrima, B. (2018). Effects Of The Bank Soundness With The Rbbr Approach (Risk Base Bank Rating) Of Cost Efficiency And Its Implications On Sharia Bank Performance In Indonesia For The Period Of 2012-2016. International Journal of Economic Research, 15(1).

Soemarso SR (3 March 2000). Going Concern Issues and Risk Environment. One Day Seminar.MAKSI,Jakarta.

Sunardi, N. (2018). Analisis Economic Value Added (Eva), Financial Value Added (FVA) Dan Market Value Added (MVA) Dengan Time Series Approach Sebagai Alat Penilaian Kinerja Keuangan (Studi Pada Industri Konstruksi (BUMN) di Indonesia Yang Listing di BEI Tahun 2013-2017). Jurnal SEKURITAS (Saham, Ekonomi, Keuangan dan Investasi), 2(1).

Sunardi, N. (2018). Kinerja Perusahan Pendekatan Du Pont System Terhadap Harga dan Return Saham (Perusahaan yang tergabung dalam Industri Real Estate dan Properti yang terdaftar di Bursa Efek Indonesia Tahun 2011-2017). JIMF (Jurnal IImiah Manajemen Forkamma), 1(3). 